\title{
Photodynamic Therapy in the Treatment of Vulvar Lichen Sclerosus: A Systematic Review of the Literature
}

\author{
Agnieszka Gerkowicz (D), Paulina Szczepanik-Kułak *(D) and Dorota Krasowska (D) \\ Department of Dermatology, Venerology and Paediatric Dermatology, Medical University of Lublin, \\ 20-081 Lublin, Poland; agerkowicz@wp.pl (A.G.); dor.krasowska@gmail.com (D.K.) \\ * Correspondence: vpaulinav@gmail.com
}

check for updates

Citation: Gerkowicz, A.;

Szczepanik-Kułak, P.; Krasowska, D. Photodynamic Therapy in the Treatment of Vulvar Lichen Sclerosus: A Systematic Review of the Literature. J. Clin. Med. 2021, 10, 5491. https:// doi.org/10.3390/jcm10235491

Academic Editor: Giuseppe Stinco

Received: 2 November 2021

Accepted: 17 November 2021

Published: 23 November 2021

Publisher's Note: MDPI stays neutral with regard to jurisdictional claims in published maps and institutional affiliations.

Copyright: (c) 2021 by the authors. Licensee MDPI, Basel, Switzerland. This article is an open access article distributed under the terms and conditions of the Creative Commons Attribution (CC BY) license (https:// creativecommons.org/licenses/by/ $4.0 /)$.

\begin{abstract}
Vulvar lichen sclerosus (VLS) is a chronic inflammatory disease involving the genital skin and mucous membrane. Patients exhibit focal atrophy and destructive scarring, with an increased risk of malignant transformation. Due to objective symptoms as well as subjective complaints, patients with VLS experience emotional distress, lowered mood, and sexual dysfunction, which is reflected in impaired health-related quality of life. Thus, the necessity of implementing appropriate therapy at the earliest possible stage of the disease in order to avoid serious complications is highlighted. We presented the systematic review of available literature, performed with MEDLINE, Cinahl, Central, Scopus, and Web of Science databases. We identified a total of twenty relevant studies which indicate that photodynamic therapy (PDT) is a valuable therapeutic modality in the treatment of VLS.
\end{abstract}

Keywords: vulvar lichen sclerosus; VLS; photodynamic therapy; PDT

\section{Introduction}

Vulvar lichen sclerosus (VLS) is a chronic inflammatory disease involving the genital skin and mucous membrane. The first description of lichen sclerosus lesions became known in 1887 [1]. Initially, no uniform terminology existed, with many synonyms being used. Nowadays, the term "vulvar lichen sclerosus" is widely applied [2]. VLS is a chronic disease with a pattern of recurrent lesions. Patients exhibit focal atrophy, destructive scarring, and associated functional impairment, with an increased risk of malignant transformation [3]. Worth mentioning, lichen sclerosus may also interest other body areas, and the genital area of the opposite sex [4].

The worldwide prevalence of lichen sclerosus ranges from $0.1 \%$ to $1.67 \%$ [5]. Of note, the exact prevalence of VLS has not been established and is probably underestimated, particularly in young women [6]. Several papers report a bimodal onset of disease, that is, in prepubertal children and postmenopausal women [2,7]. However, recent studies suggest that VLS may also affect some other age groups [5]. In terms of incidence, elderly women predominate $(3 \%)$, while lichen sclerosus affects about $0.07 \%$ of men $[8,9]$. The ratio of men to women varies between 1:3 and 1:10, and only rarely is an equal split observed [9]. Approximately $0.3 \%$ of children are estimated to be involved [10]. The etiology of VLS remains unknown, but several mechanisms have been investigated [11]. Studies suggest a multifactorial origin of the etiology, such as autoimmune mechanisms, genetic predisposition, association with viral diseases, trauma, chronic irritation, and endocrine disorders $[3,12]$.

In the early stages of VLS, well-demarcated, thin, glistening, ivory-white areas are seen, usually located in the labia minora, vaginal introitus, and fork. Tenderness and fragility, characteristic features of VLS, lead to the development of erosions, fissures, purpura, and petechiae. Fissures are particularly common between the clitoris and urethra, in the interlabial sulci, and at the base of the posterior fourchette. In addition, these lesions often occur during sexual intercourse or aggressive physical examination. With time, late complications resulting from the development of atrophic changes and scarring may appear. 
Mucocutaneous lesions are accompanied by itching, which is particularly severe at night and therefore worsens the quality of sleep, as well as intense pain, dyspareunia, or even apareunia, and impeded urinary flow. Furthermore, when the perianal area is involved, which occurs in about one-third of women, problems with defecation may occur $[2,8,11,13]$. Of concern is the association between VLS and subsequent vulvar squamous cell carcinoma (SCC). In their systematic review, Spekreijse et al. reported that the absolute risk of developing SCC in women with VLS varied between $0.21 \%$ and $3.88 \%$. Contributing factors to this risk included age, presence of vulvar intraepithelial neoplasia, long medical history of VLS, delayed diagnosis of VLS, and only partial compliance in terms of use of the topical treatment [14].

According to the guidelines published, the diagnosis of VLS is based on clinical and histopathologic features. In addition, it is necessary to exclude several other disorders $[9,15]$. Noteworthy is the possibility of employing dermoscopy as a non-invasive diagnostic method $[16,17]$.

Due to objective symptoms as well as subjective complaints, patients with VLS experience emotional distress, lowered mood, and sexual dysfunction, which is reflected in impaired health-related quality of life $[18,19]$. Thus, the necessity of implementing appropriate therapy at the earliest possible stage of the disease in order to avoid serious complications is highlighted.

The first-line treatment and the standard of care for VLS is ultrapotent topical corticosteroids (TCSs). According to the British Association of Dermatologists (BAD) guidelines published in 2018, the recommended treatment for VLS is the use of clobetasol propionate ointment $0.05 \%$ in one fingertip unit once daily for a month, then in the second month every other day and in the third month twice a week, in combination with a soap substitute and barrier preparation [20]. Topical corticosteroids are also the mainstay of treatment for exacerbations in the course of the disease [20]. The topical calcineurin inhibitors (TCIs), tacrolimus and pimecrolimus, are second-line agents that are less effective than clobetasol propionate in the treatment of VLS [21]. Other treatments for VLS include cyclosporine, phototherapy (narrowband UVB, UVA1) and photochemotherapy (PUVA), oral retinoids, and methotrexate [22]. In addition, in patients with lesions refractory to TCS, encouraging results have been obtained after using adipose tissue-derived stem cells and/or platelet-rich plasma [23]. There are also reports of the use of three energy-based methods: photodynamic therapy (PDT), high-intensity focused ultrasound (HIFU), and fractional $\mathrm{CO}_{2}$ laser $\left(\mathrm{FxCO}_{2}\right)$ [21]. Surgical procedures are often required for late complications of scarring and adhesions [21]. However, the current evidence for the efficacy of the mentioned therapies in the treatment of VLS is poor. Further research is needed to establish recommendations for these therapies.

The role of photodynamic therapy (PDT) in the treatment of VLS is of particular interest, given its high efficacy and good cosmetic outcome. According to evidence-based guidelines, it is a method with a clinical benefit, especially in terms of subjective complaints related to the presence of skin lesions. Moreover, PDT should be considered in cases refractory to standard treatment. However, the patient should be informed about the need to carry out several treatments, which contributes to a long treatment time, and about the discomfort that may be experienced during the treatments [9].

PDT is a treatment consisting in the use of a photosensitizing chemical substance to cause phototoxicity [24]. This method is based on the interaction of three non-toxic agents: the light of appropriate wavelength, photosensitizer, and oxygen, which collectively lead to selective photooxidation of lesional tissues without damage to the surrounding healthy skin [25]. In this paper, we discussed the use of PDT in VLS by performing a systematic review of the available literature.

\section{Materials and Methods}

The systematic review of the literature was performed with MEDLINE, Cinahl, Central, Scopus, and Web of Science databases complementary to PRISMA (Preferred Reporting 
Items of Systematic Reviews and Meta-Analyses) protocol. The inclusion criteria for considering studies for the review based on PICOS structure comprised the population of patients diagnosed with VLS undergoing PDT, English language publications, clinical trials, and publications from 2000-2021. The criteria of exclusion included review articles, animal studies, as well as comparative, immunological, or histopathological studies. The databases were searched using the relevant MeSH terms: "vulvar lichen sclerosus" and "photodynamic therapy". The search was performed in August 2021, with the last day to access the databases of 13 August 2021.

\section{Results}

The initial search revealed 182 results. After applying criteria of exclusion and inclusion, the database search revealed 20 records (MEDLINE $n=20$, Cinahl $n=0$, Central $n=0$, Scopus $n=0$, Web of Science $n=0$ ) published in 2005-2021 submitted for the further analysis (Figure 1).

Records identified through database searching ( $n=182$ (MEDLINE $=37$, CINAHL $=3$, CENTRAL $=12$, SCOPUS $=67$, Web of Science $=63$ )

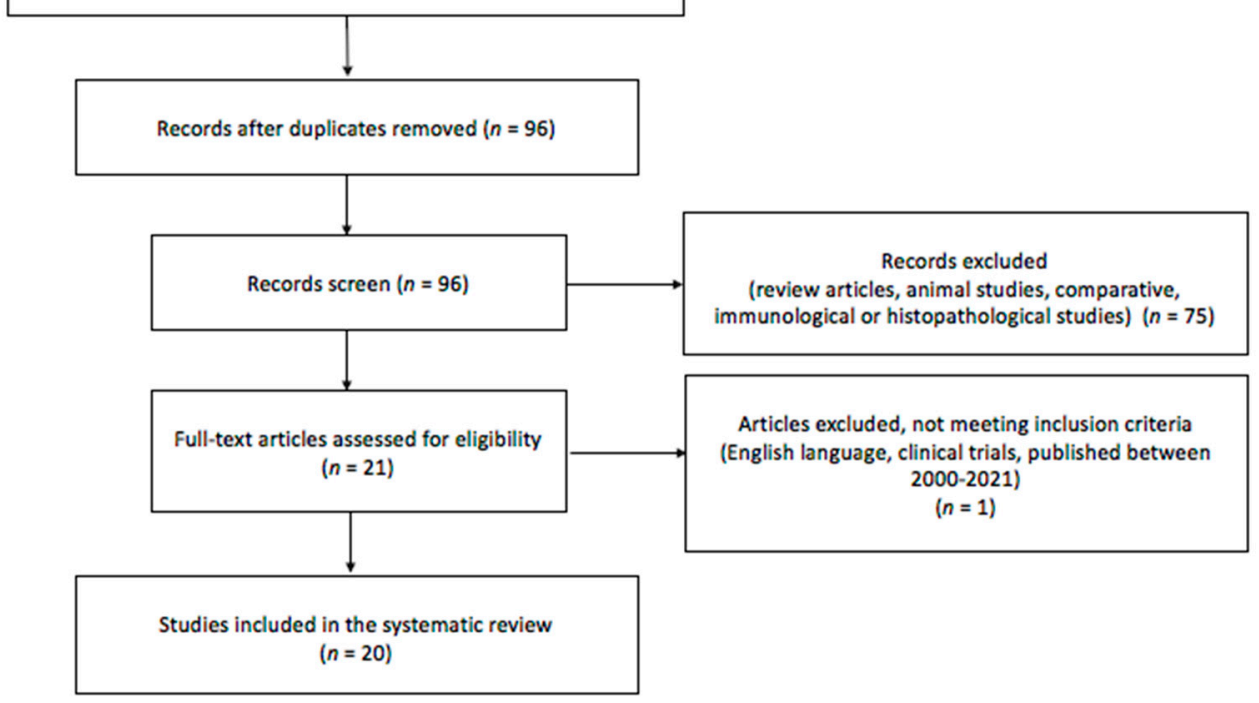

Figure 1. Literature search based on PRISMA protocol.

The studies included in the systematic review based on their publication date are presented in Table 1. 
Table 1. Studies included in this systematic review.

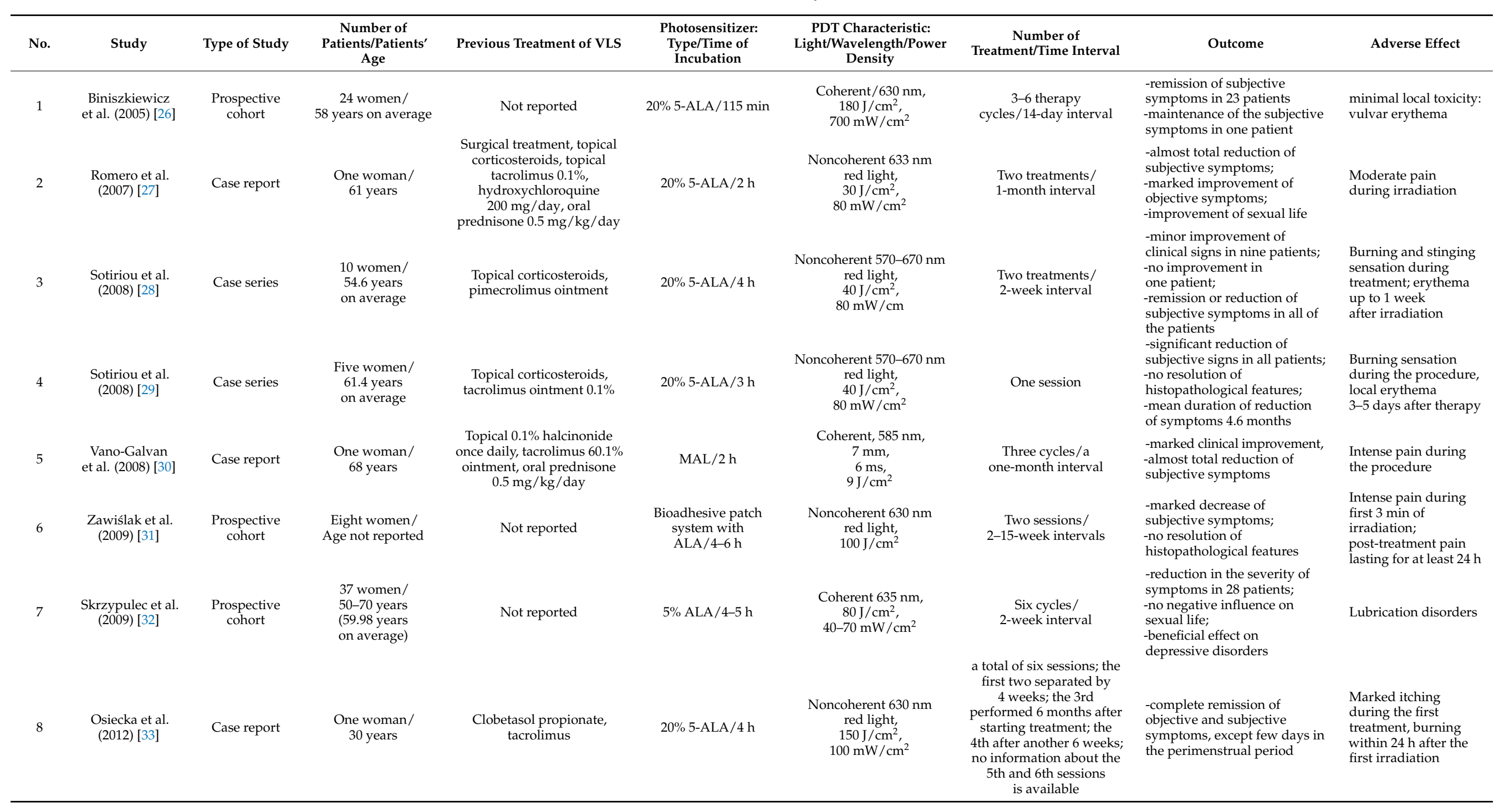


Table 1. Cont

\begin{tabular}{|c|c|c|c|c|c|c|c|c|c|}
\hline No. & Study & Type of Study & $\begin{array}{c}\text { Number of } \\
\text { Patients/Patients' } \\
\text { Age }\end{array}$ & Previous Treatment of VLS & $\begin{array}{l}\text { Photosensitizer: } \\
\text { Type/Time of } \\
\text { Incubation }\end{array}$ & $\begin{array}{c}\text { PDT Characteristic: } \\
\text { Light/Wavelength/Power } \\
\text { Density }\end{array}$ & $\begin{array}{c}\text { Number of } \\
\text { Treatment/Time Interval }\end{array}$ & Outcome & Adverse Effect \\
\hline 9 & $\begin{array}{l}\text { Imbernón-Moya } \\
\text { et al. (2016) [34] }\end{array}$ & Case series & $\begin{array}{l}\text { Eight women/ } \\
\text { seven women }> \\
60 \text { years } \\
\text { One woman: } \\
38 \text { years }\end{array}$ & $\begin{array}{l}\text { Topical corticosteroids, } \\
\text { topical calcineurin } \\
\text { inhibitors }\end{array}$ & $\mathrm{MAL} / 3 \mathrm{~h}$ & $\begin{array}{c}\text { Noncoherent } 630 \mathrm{~nm} \\
\text { red light, } \\
37 \mathrm{~J} / \mathrm{cm}^{2}, \\
70 \mathrm{~mW} / \mathrm{cm}^{2}\end{array}$ & $\begin{array}{c}1-3 \text { treatments/ } \\
6-12 \text { months interval }\end{array}$ & $\begin{array}{l}\text {-significant improvement in } \\
\text { subjective symptoms and } \\
\text { quality of life in all cases; } \\
\text {-lack of improvement in } \\
\text { clinical presentation in } \\
\text { all cases }\end{array}$ & $\begin{array}{l}\text { Mild erythema, } \\
\text { edema, burning, } \\
\text { urinary problems }\end{array}$ \\
\hline 10 & $\begin{array}{l}\text { Osiecka et al. } \\
\text { (2017) [35] }\end{array}$ & $\begin{array}{l}\text { Prospective } \\
\text { cohort }\end{array}$ & $\begin{array}{l}11 \text { women/ } \\
30-66 \text { years ( } 48 \\
\text { on average) }\end{array}$ & $\begin{array}{l}\text { Topical corticosteroids, } \\
\text { estrogens, topical } \\
\text { calcineurin inhibitors }\end{array}$ & $20 \% 5-\mathrm{ALA} / 5 \mathrm{~h}$ & $\begin{array}{c}\text { Noncoherent } \\
540 \pm 15 \mathrm{~nm} \text { green light, } \\
62.5 \mathrm{~J} / \mathrm{cm}^{2} \\
85 \mathrm{~mW} / \mathrm{cm}^{2} ; \\
\text { fractionated-2 }-2 \text { in } \\
\text { irradiation, then } \\
1 \text { min pause }\end{array}$ & $\begin{array}{l}\text { Three treatments/ } \\
\text { 2-week interval }\end{array}$ & $\begin{array}{l}\text {-complete resolution of } \\
\text { objective symptoms in } 5 / 5 \\
\text { patients } 2 \text { months after PDT; } \\
\text {-complete resolution of } \\
\text { subjective symptoms } 2 \\
\text { months after PDT in } 9 / 11 \\
\text { women, one remaining in } \\
\text { moderate intensity, the other } \\
\text { one in low intensity } \\
\text {-complete or partial remission }\end{array}$ & $\begin{array}{l}\text { Itching as the main } \\
\text { symptom, weak or } \\
\text { moderate pain, mild } \\
\text { edema, and erythema }\end{array}$ \\
\hline 11 & $\begin{array}{l}\text { Maździarz et al. } \\
\text { (2017) [36] }\end{array}$ & $\begin{array}{l}\text { Prospective } \\
\text { cohort }\end{array}$ & $\begin{array}{c}102 \text { women/ } \\
\text { 19-85 years ( } 55.08 \\
\text { on average) }\end{array}$ & Topical corticosteroids & $\begin{array}{l}\text { 5\% 5-ALA with } 2 \% \\
\text { DMSO } / 3 \mathrm{~h}\end{array}$ & $\begin{array}{c}\text { Noncoherent 590-760 nm, } \\
120 \mathrm{~J} / \mathrm{cm}^{2}, \\
204 \mathrm{~mW} / \mathrm{cm}^{2}\end{array}$ & $\begin{array}{c}10 \text { applications/ } \\
\text { one-week interval }\end{array}$ & $\begin{array}{l}\text { in } 87 \% \text { of patients, } \\
\text {-decrease in the number of } \\
\text { objective signs (improvement } \\
\text { rate } 100 \%-70 \% \text { in } 60.78 \% \text { of } \\
\text { patients, around } 50 \% \text { in } \\
16.67 \% \text { of patients, } 30 \% \text { in } \\
9.8 \% \text {, less than } 30 \% \text { in } 12.75 \% \text { ) }\end{array}$ & $\begin{array}{l}\text { Paresthesia during } \\
\text { irradiation in } \\
39 \text { patients, in } \\
12 \text { patients swelling } \\
\text { for a few hours }\end{array}$ \\
\hline 13 & $\begin{array}{l}\text { Lan et al. } \\
\text { (2018) [38] }\end{array}$ & Case series & $\begin{array}{c}10 \text { women/ } \\
51 \text { years on average }\end{array}$ & $\begin{array}{l}\text { Topical corticosteroids, } \\
\text { topical calcineurin } \\
\text { inhibitors, cryosurgery }\end{array}$ & $10 \% 5$-ALA $/ 3 \mathrm{~h}$ & $\begin{array}{c}\text { Noncoherent } \\
635 \pm 15 \mathrm{~nm} \text { red light, } \\
100 \mathrm{~J} / \mathrm{cm}^{2} \\
100 \mathrm{~mW} / \mathrm{cm}^{2}\end{array}$ & $\begin{array}{l}\text { Three sessions/ } \\
\text { 2-week interval }\end{array}$ & $\begin{array}{l}\text {-resolution of subjective } \\
\text { symptoms in } 10 \text { patients, } \\
\text {-complete resolution of } \\
\text { sexual dysfunction; } \\
\text {-improvement of quality } \\
\text { of life; } \\
\text {-significant decrease of } \\
\text { lesion size; } \\
\text {-no recurrences during the } \\
\text { observation period }\end{array}$ & $\begin{array}{l}\text { Short-term pain, } \\
\text { burning, erythema, } \\
\text { and edema during } \\
\text { and after irradiation }\end{array}$ \\
\hline 14 & $\begin{array}{l}\text { Maździarz } \\
\text { (2019) [39] }\end{array}$ & $\begin{array}{l}\text { Prospective } \\
\text { cohort }\end{array}$ & $\begin{array}{l}\text { Two women/ } \\
22 \text { and } 23 \text { years }\end{array}$ & Topical corticosteroids & $\begin{array}{l}\text { 5\% 5-ALA with 2\% } \\
\text { DMSO } / 3 \mathrm{~h}\end{array}$ & $\begin{array}{c}\text { Noncoherent } 590-760 \mathrm{~nm}, \\
120 \mathrm{~J} / \mathrm{cm}^{2}, \\
204 \mathrm{~mW} / \mathrm{cm}^{2}\end{array}$ & $\begin{array}{l}10 \text { applications / } \\
\text { one-week interval }\end{array}$ & $\begin{array}{l}\text { remission of vulvar lesions } \\
\text { and negative HPV DNA } \\
\text { results in one patient }\end{array}$ & $\begin{array}{l}\text { Short-term pain and } \\
\text { burning sensation }\end{array}$ \\
\hline
\end{tabular}


Table 1. Cont.

\begin{tabular}{|c|c|c|c|c|c|c|c|c|c|}
\hline No. & Study & Type of Study & $\begin{array}{c}\text { Number of } \\
\text { Patients/Patients' } \\
\text { Age } \\
\end{array}$ & Previous Treatment of VLS & $\begin{array}{l}\text { Photosensitizer: } \\
\text { Type/Time of } \\
\text { Incubation }\end{array}$ & $\begin{array}{c}\text { PDT Characteristic: } \\
\text { Light/Wavelength/Power } \\
\text { Density }\end{array}$ & $\begin{array}{c}\text { Number of } \\
\text { Treatment/Time Interval }\end{array}$ & Outcome & Adverse Effect \\
\hline 15 & $\begin{array}{l}\text { Zhang (2020) } \\
\text { [40] }\end{array}$ & Case series & $\begin{array}{l}30 \text { women/ } \\
48.23 \text { years } \\
\text { on average }\end{array}$ & $\begin{array}{l}\text { Topical corticosteroids, } \\
\text { vitamin E, Haijisin }\end{array}$ & $20 \% 5$-ALA $/ 3 \mathrm{~h}$ & $\begin{array}{l}\text { Noncoherent 631-635 nm } \\
\text { red light, } \\
60-90 \mathrm{~mW} / \mathrm{cm}^{2}\end{array}$ & $\begin{array}{l}\text { Three sessions/ } \\
\text { 2-week interval }\end{array}$ & $\begin{array}{l}\text {-total resolution of pruritus in } \\
25 \text { patients, improvement in } \\
\text { three patients, } \\
\text {-complete resolution of pain in } \\
28 \text { patients, mild to moderate } \\
\text { pain in two patients } \\
\text {-total resolution of sexual } \\
\text { dysfunction in } 26 \text { patients, } \\
\text { moderate to severe sexual } \\
\text { intercourse persisting in } \\
4 \text { patients }\end{array}$ & $\begin{array}{l}\text { Short-term pain, } \\
\text { burning, erythema, } \\
\text { and edema }\end{array}$ \\
\hline 16 & $\begin{array}{l}\text { Li et al. } \\
\text { (2020) [41] }\end{array}$ & $\begin{array}{l}\text { Prospective } \\
\text { cohort }\end{array}$ & $\begin{array}{l}10 \text { women/ } \\
35.4 \text { years } \\
\text { on average }\end{array}$ & Topical corticosteroids & $20 \% 5-A L A / 3 \mathrm{~h}$ & $\begin{array}{l}\text { Coherent } 635 \mathrm{~nm} \\
\text { red light, } \\
80 \mathrm{~J} / \mathrm{cm}^{2}, \\
80 \mathrm{~mW} / \mathrm{cm}^{2}\end{array}$ & $\begin{array}{l}4-9 \text { sessions, depending } \\
\text { on the condition }\end{array}$ & $\begin{array}{l}\text {-significant reduction in } \\
\text { objective and subjective } \\
\text { symptoms of VLS and } \\
\text { improvement in quality of life } \\
\text {-no recurrence of lesions } \\
3 \text { months after PDT } \\
\text {-recurrence of lesions } \\
6 \text { months after PDT in } \\
\text { two patients } \\
\text {-VLS areas reduced and } \\
\text { thinned after three }\end{array}$ & $\begin{array}{l}\text {-mild to moderate } \\
\text { pain in eight women } \\
\text { undergoing PDT } \\
\text {-burning sensation, } \\
\text { swelling, erythema in } \\
\text { six women, lasting up } \\
\text { to } 5 \text { days } \\
\text { after irradiation }\end{array}$ \\
\hline 17 & $\begin{array}{l}\text { Cao et al. } \\
\text { (2020) [42] }\end{array}$ & Case report & $\begin{array}{l}\text { One woman/ } \\
72 \text { years }\end{array}$ & $\begin{array}{c}\text { Clobetasol propionate } \\
0.5 \% \text { cream }\end{array}$ & $10 \% 5-A L A / 3 \mathrm{~h}$ & $\begin{array}{c}\text { Noncoherent } 635 \mathrm{~nm} \\
\text { red light, } \\
100 \mathrm{~J} / \mathrm{cm}^{2} \\
200 \mathrm{~mW} / \mathrm{cm}^{2}\end{array}$ & $\begin{array}{l}\text { Three treatments at } \\
\text { 2-week intervals, then } \\
\text { after one month, a } \\
\text { holmium laser treatment } \\
\text { in combination with the } \\
\text { last PDT }\end{array}$ & $\begin{array}{l}\text { PDT treatments } \\
\text {-almost complete remission } \\
\text { after last combined laser + } \\
\text { PDT treatment } \\
\text {-relief of subjective symptoms } \\
\text {-no recurrence of lesions after } \\
1 \text { year of follow-up } \\
\text {-satisfaction of patients with } \\
\text { the treatment }\end{array}$ & $\begin{array}{l}\text { Mild swelling and } \\
\text { erythema after each } \\
\text { treatment, moderate } \\
\text { pain }\end{array}$ \\
\hline 18 & $\begin{array}{l}\text { Liu et al. } \\
\text { (2021) [43] }\end{array}$ & $\begin{array}{l}\text { Prospective } \\
\text { cohort }\end{array}$ & $\begin{array}{c}24 \text { women/ } \\
21-61 \text { years } \\
\text { (45 years } \\
\text { on average) }\end{array}$ & Not reported & $20 \% 5-A L A / 3 \mathrm{~h}$ & $\begin{array}{l}\text { Noncoherent } 633 \mathrm{~nm} \\
\text { red light, } \\
60 \mathrm{~mW} / \mathrm{cm}^{2}\end{array}$ & $\begin{array}{l}\text { Six treatments/ } \\
\text { 2-week intervals }\end{array}$ & $\begin{array}{l}\text {-significant remission of } \\
\text { clinical signs } \\
\text {-gradual alleviation of } \\
\text { subjective symptoms with } \\
\text { subsequent PDT treatments } \\
\text {-marked improvement of the } \\
\text { dermoscopic features }\end{array}$ & $\begin{array}{l}\text {-in } 19 \text { cases, transient } \\
\text { complaints of pain } \\
(<24 \mathrm{~h}) \\
\text {-in seven cases, } \\
\text { erosions healed } \\
\text { within one week } \\
\text { after PDT }\end{array}$ \\
\hline
\end{tabular}


Table 1. Cont.

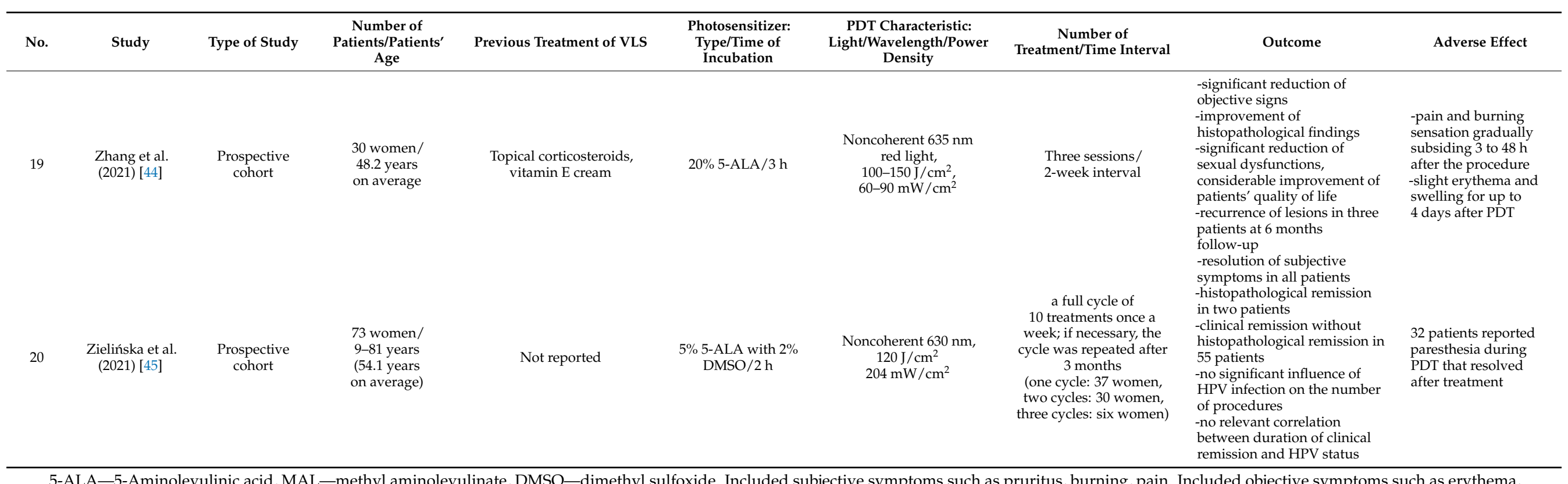

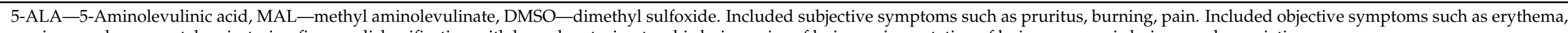
erosions, ecchymoses, telangiectasias, fissures, lichenification with hyperkeratosis, atrophic lesions, size of lesions, pigmentation of lesions, purpuric lesions, and excoriation. 


\subsection{Characteristics of Included Studies}

The majority $(n=11)$ of the included studies were prospective, with the remainder involving case series $(n=5)$ and case reports $(n=4)$. Only one study comprised a controlled cohort [37]. The number of reported patients ranged from 1 up to 102.

The study group consisted of women between the age range of 9 and 85 years (52 on average) with a clinically and histopathologically confirmed diagnosis of VLS. Notably, Cao et al. described the treatment of the hyperkeratotic form of VLS [42]. The duration of the disease ranged from 3 months to 29 years. Patients had a history of receiving local, systemic, or surgical treatment that did not lead to significant clinical improvement. The follow-up time for patients was under 12 months in the vast majority of studies.

\subsection{Photodynamic Therapy Parameters of Included Studies}

For the majority of studies ( $n=17), 5$-aminolevulinate (5-ALA) was used as the photosensitizer. The concentration range of 5-ALA varied, being 20\% $(n=10), 10 \%(n=3)$, and $5 \%(n=4)$. Of particular interest, Zawiślak et al. described the use of a bioadhesive patch system in which the estimated dose of 5-ALA was $38 \mathrm{mg} / \mathrm{cm}^{2}$. In addition, some investigators used 5-ALA with the addition of dimethyl sulfoxide (DMSO) at a concentration of $2 \%$ or $20 \%(n=4)$, mainly due to the increased efficacy of the treatments resulting from the higher penetration of 5-ALA into deeper skin layers [36,37,40,45]. Methyl aminolevulinate (MAL) was employed in two studies [30,34]. The duration of the maintenance of the photosensitizer on the skin ranged from 115 min to $6 \mathrm{~h}$, with a clear dominance of the 3-h period $(n=11)$.

Regarding the light source, red light was used in 19 studies, and one study described the use of green light. For most studies $(n=18)$, the range of wavelengths used coincided with the preferred therapeutic window of $600-800 \mathrm{~nm}$ for PDT. In 14 papers, the wavelength oscillated between $630-635 \mathrm{~nm}$. Notably, Olejek et al., in a study on a large group of patients $(n=100)$, applied two light sources [37]. Group I received treatment with red light (DIOMED $630 \mathrm{~nm}$ ) and group II with a combination of visible light and waterfiltered infrared A light (PhotoDyn ${ }^{\circledR} 750$ Heine.Med GmbH \& Co. KG Müllheim, Germany, $580-1400 \mathrm{~nm}$ ). Both groups experienced a significant reduction in the intensiveness of subjective complaints, with no significant difference between them [37].

There was quite a wide variance in the treatment parameters, that is, dose and intensity. The doses fluctuated between 9 and $180 \mathrm{~J} / \mathrm{cm}^{2}$, with a range of $100-150 \mathrm{~J} / \mathrm{cm}^{2}$ in eight studies. For light intensity, a minimum of 40 and a maximum of $700 \mathrm{~mW} / \mathrm{cm}^{2}$ were employed. In eight studies, the light intensity used covered $80 \mathrm{~mW} / \mathrm{cm}^{2}$. The number of treatments performed varied between 1 and 10, with the highest number of three procedures $(n=5)$. Moreover, PDT treatments were performed at different intervals. The majority were 2 weeks $(n=9)$, and less frequently 1 week and 4 weeks $(n=4$, $n=3$, respectively).

\subsection{Main Outcomes}

Special concern was given to subjective symptoms, especially pruritus, which is considered as a major discomfort for patients with VLS. Sixteen studies have described the efficacy of PDT in the resolution of pruritus. The considerable reduction of itching as measured by VAS or VRS scales was reported in eight publications $[28,29,31,34,35,38,40,41]$. Other studies indicated high therapeutic efficacy of PDT in relieving pruritus, in some cases of a gradual nature with subsequent treatments $[27,30,32,33,37,42,43]$.

Because of the location of the lesions, VLS favors the development of sexual dysfunction. Seven studies have addressed this issue [27,32,33,38,40,41,45]. Only one study assessed patient satisfaction with treatment [38]. Lan et al. noted that $9 / 10$ patients were highly satisfied, and $1 / 10$ patients was satisfied [38].

In addition to the effect on subjective symptoms, there have been reports of relief of objective features after PDT. Romero et al. and Osiecka et al. described healing of erosions $[27,33,35]$. However, in a study by Romero et al. only the external erosions were 
cleared, whereas the deeper ones remained [27]. Other cases of clinical enhancement were due to a reduction in the size of VLS foci or their complete cessation [38,42-44]. Of note, Li et al. reported a significant reduction in the total objective score 6 months after PDT, which included symptoms such as leukoplakia, erythema, hyperkeratosis, purpuric lesions, and itching-related excoriations [41]. There are also reports of poor effects of PDT on the clinical features of VLS, despite satisfactory resolution of subjective complaints. Sotiriou et al. described a mediocre improvement in terms of clinical signs (hyperkeratosis, atrophy, induration, depigmentation) in 9/10 women receiving PDT and a complete lack of improvement in 1/10 patients [28]. In addition, Imbernón-Moya demonstrated that the evaluation of VLS lesions regarding clinical and morphological aspects was similar before and after PDT [34].

Histopathological examinations after PDT were performed in four publications [29,31,44,45]. The study by Sotiriou et al. emphasized the effect of PDT on subjective symptoms only, as no improvement in histopathological findings was found [29]. Zawiślak et al. also showed no histopathological improvement [31]. However, based on immunohistochemical evaluation, they found an increase in the apoptotic index, which allowed them to conclude that PDT has an effect by inducing apoptosis within the treated tissues [31]. Zhang et al. observed resolution of chronic inflammation and acellular collagen bundles and improvement in the epithelial vacuolar degeneration [44]. However, in the study by Zielińska et al., histological improvement was found in only 2/73 of the treated women [45]. Different diagnostic tools were used to objectively evaluate the effectiveness of treatment, including: dermoscopy, photodynamic diagnostics, or vulvoscopy [32,36,37,43].

\subsection{Adverse Effects}

The observed overall good tolerability of PDT treatment and short persistence of complications are worth mentioning. In none of the studies was the continuation of treatment abandoned due to complications. However, adverse effects have been reported in almost every publication, except for the study by Olejek et al. in which no complications were noted [37]. Only Vano-Galvan described the patient's reluctance to restart treatment when symptoms worsened at 4 months after the end of treatment. The reason for this was the intensity of the pain suffered during PDT and poor tolerance of local anesthesia [30].

The predominant complaint mentioned in the studies $(n=12)$ was mild to intense pain, which sometimes exceeded the duration of the procedure but was short-lived. Notably, not all studies reported the use of anesthesia preoperatively or during the procedure. Vano-Galvan et al. used intralesional injections of mepivacaine $2 \%$ before each procedure, and Zawiślak provided oral co-codamol and topical lignocaine gel [30,31]. Zhang et al. administered oral analgesics and lignocaine in 2 of 28 and 14 of 30 patients, respectively [40,44]. Imbernón-Moya et al. used midazolam and general anesthesia (propofol) [34]. The PDT was not discontinued completely in any case due to severe pain, and only Biniszkiewicz et al. described the need for short breaks during the course of the procedure in some patients [26].

Erythematous lesions $(n=10)$, lasting up to a week after treatment, were another frequently observed side effect of PDT. Burning sensation $(n=9)$ and the presence of local swelling $(n=7)$ were reported slightly less frequently. Pruritus, paresthesia, urinary problems, erosions, and lubrication disorders were much less common.

Of note is the work of Osiecka et al., in which PDT was performed using green light to improve the tolerability of the procedure. In addition, a fractionated irradiation model was used, that is, two minutes of exposure was separated by a one-minute interval [35]. However, patients experienced pruritus of varying intensity as well as mild to moderate pain, which, in comparison with red light studies, for example, Zawiślak or Maździarz, implied poorer tolerance of the treatment $[31,36]$. 


\subsection{Recurrences}

VLS is a chronic disease, so relapses and exacerbations are part of its course. Romero et al. and Sotiriou et al., during follow-up after PDT (3-6 months and 3 months, respectively), observed mild symptoms of VLS, manageable with topical corticosteroids [27,29]. Osiecka et al. described the reappearance of erosions in one woman as early as 4 months after treatment and in two women after 6 months, accompanied by a burning sensation. In addition, during the 6 months after PDT, three patients reported weak pruritus, occurring mainly before menstruation [35]. Vano-Galvan's case report presented a major recurrence 4 months after treatment, whereby the patient refused to continue PDT [30]. In ImbernónMoya's study, recurrence of lesions occurred between 3 and 9 months after treatment [34]. Li et al. observed a relapse in $2 / 10$ patients after 6 months [41]. Zhang et al. reported recurrence in 3/30 women 6 months after treatment [44]. Furthermore, Olejek et al. noted pruritus in $8 \%$ of female patients during a 24-month follow-up [37].

However, recurrence of VLS was not described in other studies. It is worth mentioning that Maździarz et al. confirmed the absence of disease exacerbation in vulvoscopy performed one year after PDT [39].

\section{Discussion}

Currently, PDT has many applications in the treatment of a variety of skin disorders, mainly non-melanoma skin cancers [46]. Of note, this method in dermatology was used by Kennedy et al. for the first time [47]. The mechanism of PDT is based on the interaction of three elements: photosensitizer, the light of the appropriate wavelength, and oxygen. The purpose of this interaction is the production of cytotoxic reactive oxygen species that selectively destroy damaged tissue while leaving normal skin intact [47]. However, the exact mechanism of action of PDT in the treatment of VLS remains uncertain. It is thought to primarily target skin sclerosis as PDT has been shown to induce apoptosis of lymphocytes and keratinocytes and to alter the expression of both cytokines and metalloproteinases that play a role in skin remodeling [48]. However, Olejek et al. described the effect of PDT on the immune status of patients after the procedures, that is, a significant reduction in antinuclear antibody titers, which places PDT as a method with immuno-modulatory potential [37]. Moreover, Maździarz et al. presented the efficacy of PDT in concomitant infection with high-risk HPV types, which establishes PDT as a prophylactic method in cancer development [39]. According to Zielińska et al., treatment of VLS in the absence or confirmed presence of HPV infection is equally effective [45].

The first-line treatment for VLS is topical corticosteroids. When used chronically, these agents possess numerous side effects [49]. Moreover, the risk of VLS recurrence after their use is very high [50]. Noteworthy are the results of a single open-label study comparing ALA-PDT and the application of clobetasol propionate $0.05 \%$ ointment by 43 patients with VLS [51]. PDT treatments were performed four times every 2 weeks, and clobetasol was applied once daily for 8 weeks. It was found that clinical symptoms and subjective complaints improved in both groups. However, it was ALA-PDT that led to a higher clinical response rate and a longer remission period [51].

Biniszkiewicz et al. stated that PDT, because of its excellent cosmetic effect, lack of complications in the form of scarring, or changes in the structure and function of the treated tissues, should be performed as a therapy preceding more invasive procedures [26]. In view of the above and the lack of effect on reproductive capacity, PDT stands as a method also for the treatment of young women of childbearing potential [32]. PDT is considered an affordable method [26]. In addition, thanks to the possibility of using a form of a patch containing photosensitizer, it becomes an outpatient procedure, which is convenient and timesaving for patients [31].

Undoubtedly, VLS significantly affects the mental and physical health of female patients. Not only is the architecture and morphology of the vulva altered, but a wide range of subjective complaints are also experienced. The effectiveness of PDT in remission of symptoms of the disease, improvement of sexual life, and mood disorders allows making 
patients' quality of life better. Based on the literature review, PDT for VLS apparently represents a promising therapeutic modality. In all of the papers, there was an improvement, reflected in the resolution of subjective and/or objective symptoms. Although some of the publications did not demonstrate the clinical efficacy of PDT in the treatment of VLS, none of them reported lesion exacerbation. However, a significant limitation in terms of assessing the efficacy of PDT was the paucity of controlled studies.

The histopathological findings considered demand a careful approach. The reported lack of improvement indicates the need for continued follow-up of patients for progression of lesions to malignancy. Of note, VLS, as an intractable dermatosis in some cases, will not change histologically. However, the reported evidence of apoptosis indicates the therapeutic effect of PDT [31].

In all reported cases, PDT was performed as the next step, not as first-line treatment. This emphasizes the role of PDT to be a therapeutic option for refractory lesions to the previous treatments. It may also be safely repeated a number of times as it is not associated with the development of resistance [41]. However, in order to reduce the number of procedures, to shorten the treatment period, and to avoid the side effects that accompany the interventions, it is worth considering the addition of a holmium laser treatment [42].

There was certainly a notable heterogeneity in the publications in regard to the photosensitizing substance and its retention length on the skin, the treatment parameters, their number, and the time intervals between them. In addition, the studies used different indices to assess clinical improvement. In our opinion, dermoscopy deserves special at-tention, which, as a non-invasive, available, and inexpensive method, allowed the evaluation of the therapeutic response at early stages [43]. In contrast, concordance was seen for the study cohort, which consisted of peri-menopausal women.

Interestingly, Declerq et al. recently reported a PDT protocol for VLS on the basis of a systematic review of the literature [52]. Patients should urinate before the procedure; then, the vulva is to be washed with $0.9 \% \mathrm{NaCl}$. The photosensitizer, $5 \% \mathrm{ALA}$, has to be applied under the occlusion with a margin of $1 \mathrm{~cm}$. The incubation period is supposed to be $3 \mathrm{~h}$, and red light of $590-760 \mathrm{~nm}$, at a dose of $120 \mathrm{~J} / \mathrm{cm}^{2}$, and an intensity of $204 \mathrm{~mW} / \mathrm{cm}^{2}$ should be used for irradiation. In addition, the authors suggested the practice of blue light photodiagnostics and xylocaine or water spray alleviate side effects during the procedure [52].

\section{Conclusions}

The results of this systematic review of the literature indicated that PDT is a valuable therapeutic modality in the treatment of VLS, especially those which are refractory to current treatment. It is undoubtedly a high-efficacy method, particularly in terms of resolution of subjective symptoms, which is reflected in an improvement in the quality of life of treated women. This method has a high safety profile and in most cases is associated with the development of mild side effects. Treatments may be repeated several times at no risk of resistance development. Moreover, PDT is characterized by a lack of negative effects on women's reproductive potential and high patient satisfaction with the treatments. The good cosmetic effect of PDT and its potential for cancer prevention are also worth mentioning. However, the lack of histopathological remission should prompt a long-term observation of patients for cancer progression.

Author Contributions: Conceptualization, A.G.; writing—original draft preparation, P.S.-K.; writingreview and editing, A.G.; supervision, D.K. All authors have read and agreed to the published version of the manuscript.

Funding: This research received no external funding.

Institutional Review Board Statement: Not applicable.

Informed Consent Statement: Not applicable.

Data Availability Statement: Data sharing not applicable. 
Conflicts of Interest: The authors declare no conflict of interest.

\section{References}

1. Darier, J. Lichen plan sclereux. Ann. Dermatol. Syph. 1892, 23, 833-887.

2. Fistarol, S.K.; Itin, P.H. Diagnosis and treatment of lichen sclerosus: An update. Am. J. Clin. Dermatol. 2013, 14, 27-47. [CrossRef]

3. Tran, D.A.; Tan, X.; Macri, C.J.; Goldstein, A.T.; Fu, S.W. Lichen Sclerosus: An autoimmunopathogenic and genomic enigma with emerging genetic and immune targets. Int. J. Biol. Sci. 2019, 15, 1429-1439. [CrossRef] [PubMed]

4. Campolmi, P.; Cannarozzo, G.; Bennardo, L.; Clementi, A.; Sannino, M.; Nisticò, S. Fractional Micro-Ablative $\mathrm{CO}_{2}$ Laser as Therapy in Penile Lichen Sclerosus: $\mathrm{CO}_{2}$ Laser to Treat Penile Lichen Sclerosus. J. Lasers Med Sci. 2021, 12, e61. [CrossRef]

5. Jabłonowska, O.; Woźniacka, A.; Żebrowska, A. Lichen sclerosus. Dermatol. Rev. Przeglad Dermatol. 2021, 108, 126-136. [CrossRef]

6. Melnick, L.E.; Steuer, A.B.; Bieber, A.K.; Wong, P.W.; Pomeranz, M.K. Lichen sclerosus among women in the United States. Int. J. Women's Dermatol. 2020, 6, 260-262. [CrossRef]

7. Cooper, S.M.; Ali, I.; Baldo, M.; Wojnarowska, F. The association of lichen sclerosus and erosive lichen planus of the vulva with autoimmune disease: A case-control study. Arch. Dermatol. 2008, 144, 1432-1435. [CrossRef]

8. Kirtschig, G. Lichen Sclerosus-Presentation, Diagnosis and Management. Dtsch. Ärzteblatt Int. 2016, 113, 337-343. [CrossRef] [PubMed]

9. Kirtschig, G.; Becker, K.; Günthert, A.; Jasaitiene, D.; Cooper, S.; Chi, C.C.; Kreuter, A.; Rall, K.K.; Aberer, W.; Riechardt, S.; et al Evidence-based (S3) Guideline on (anogenital) Lichen sclerosus. J. Eur. Acad. Dermatol. Venereol. 2015, 29, e1-e43. [CrossRef]

10. Dinh, H.; Purcell, S.M.; Chung, C.; Zaenglein, A.L. Pediatric Lichen Sclerosus: A Review of the Literature and Management Recommendations. J. Clin. Aesthet. Dermatol. 2016, 9, 49-54. [PubMed]

11. Singh, N.; Ghatage, P. Etiology, Clinical Features, and Diagnosis of Vulvar Lichen Sclerosus: A Scoping Review. Obstet. Gynecol. Int. 2020, 2020, 7480754. [CrossRef] [PubMed]

12. Kwok, R.; Shah, T.T.; Minhas, S. Recent advances in understanding and managing Lichen Sclerosus. F1000Research 2020, 9, F1000. [CrossRef] [PubMed]

13. Paulis, G.; Berardesca, E. Lichen sclerosus: The role of oxidative stress in the pathogenesis of the disease and its possible transformation into carcinoma. Res. Rep. Urol. 2019, 11, 223-232. [CrossRef]

14. Spekreijse, J.J.; Streng, B.M.M.; Vermeulen, R.F.M.; Voss, F.O.; Vermaat, H.; van Beurden, M. The risk of developing squamous cell carcinoma in patients with anogenital lichen sclerosis: A systematic review. Gynecol. Oncol. 2020, 157, 671-677. [CrossRef] [PubMed]

15. Hasegawa, M.; Ishikawa, O.; Asano, Y.; Sato, S.; Jinnin, M.; Takehara, K.; Fujimoto, M.; Yamamoto, T.; Ihn, H. Diagnostic criteria, severity classification and guidelines of lichen sclerosus et atrophicus. J. Dermatol. 2018, 45, 891-897. [CrossRef]

16. Errichetti, E.; Lallas, A.; Apalla, Z.; Di Stefani, A.; Stinco, G. Dermoscopy of Morphea and Cutaneous Lichen Sclerosus: Clinicopathological Correlation Study and Comparative Analysis. Dermatology 2017, 233, 462-470. [CrossRef]

17. Ankad, B.S.; Beergouder, S.L. Dermoscopic patterns in lichen sclerosus: A report of three cases. Indian Dermatol. Online J. 2015, 6, 237-240. [CrossRef] [PubMed]

18. Van de Nieuwenhof, H.P.; Meeuwis, K.A.; Nieboer, T.E.; Vergeer, M.C.; Massuger, L.F.; De Hullu, J.A. The effect of vulvar lichen sclerosus on quality of life and sexual functioning. J. Psychosom. Obstet. Gynaecol. 2010, 31, 279-284. [CrossRef]

19. Felmingham, C.; Chan, L.; Doyle, L.W.; Veysey, E. The Vulval Disease Quality of Life Index in women with vulval lichen sclerosus correlates with clinician and symptom scores. Australas. J. Dermatol. 2020, 61, 110-118. [CrossRef]

20. Akel, R.; Fuller, C. Updates in lichen sclerosis: British Association of Dermatologists guidelines for the management of lichen sclerosus 2018. Br. J. Dermatol. 2018, 178, 823-824. [CrossRef]

21. Krapf, J.M.; Mitchell, L.; Holton, M.A.; Goldstein, A.T. Vulvar Lichen Sclerosus: Current Perspectives. Int. J. Women's Health 2020, 12, 11-20. [CrossRef] [PubMed]

22. Lewis, F.M.; Tatnall, F.M.; Velangi, S.S.; Bunker, C.B.; Kumar, A.; Brackenbury, F.; Mohd Mustapa, M.F.; Exton, L.S. British Association of Dermatologists guidelines for the management of lichen sclerosus, 2018. Br. J. Dermatol. 2018, 178, 839-853. [CrossRef] [PubMed]

23. Eshtiaghi, P.; Sadownik, L.A. Fact or Fiction? Adipose-Derived Stem Cells and Platelet-Rich Plasma for the Treatment of Vulvar Lichen Sclerosus. J. Low. Genit. Tract Dis. 2019, 23, 65-70. [CrossRef]

24. Del Duca, E.; Manfredini, M.; Petrini, N.; Farnetani, F.; Chester, J.; Bennardo, L.; Schipani, G.; Tamburi, F.; Sannino, M.; Cannarozzo, G.; et al. Daylight photodynamic therapy with 5-aminolevulinic acid 5\% gel for the treatment of mild-to-moderate inflammatory acne. Ital. J. Dermatol. Venerol. 2021, 156, 46-50. [CrossRef] [PubMed]

25. Gunaydin, G.; Gedik, M.E.; Ayan, S. Photodynamic Therapy for the Treatment and Diagnosis of Cancer-A Review of the Current Clinical Status. Front. Chem. 2021, 9, 686303. [CrossRef]

26. Biniszkiewicz, T.; Olejek, A.; Kozak-Darmas, I.; Sieron, A. Therapeutic effects of 5-ALA-induced photodynamic therapy in vulvar lichen sclerosus. Photodiagnosis Photodyn. Ther. 2005, 2, 157-160. [CrossRef]

27. Romero, A.; Hernández-Núñez, A.; Córdoba-Guijarro, S.; Arias-Palomo, D.; Borbujo-Martínez, J. Treatment of recalcitrant erosive vulvar lichen sclerosus with photodynamic therapy. J. Am. Acad. Dermatol. 2007, 57, 46-47. [CrossRef]

28. Sotiriou, E.; Panagiotidou, D.; Ioannidis, D. An open trial of 5-aminolevulinic acid photodynamic therapy for vulvar lichen sclerosus. Eur. J. Obstet. Gynecol. Reprod. Biol. 2008, 141, 187-188. [CrossRef] 
29. Sotiriou, E.; Apalla, Z.; Patsatsi, A.; Panagiotidou, D. Recalcitrant vulvar lichen sclerosis treated with aminolevulinic acidphotodynamic therapy: A report of five cases. J. Eur. Acad. Dermatol. Venereol. 2008, 22, 1398-1399. [CrossRef]

30. Vano-Galvan, S.; Fernandez-Guarino, M.; Beà-Ardebol, S.; Perez, B.; Harto, A.; Jaen, P. Successful treatment of erosive vulvar lichen sclerosus with methylaminolaevulinic acid and laser-mediated photodynamic therapy. J. Eur. Acad. Dermatol. Venereol. 2009, 23, 71-72. [CrossRef]

31. Zawislak, A.A.; McCluggage, W.G.; Donnelly, R.F.; Maxwell, P.; Price, J.H.; Dobbs, S.P.; McClelland, H.R.; Woolfson, A.D.; Mccarron, P.A. Response of vulval lichen sclerosus and squamous hyperplasia to photodynamic treatment using sustained topical delivery of aminolevulinic acid from a novel bioadhesive patch system. Photodermatol. Photoimmunol. Photomed. 2009, 25, 111-113. [CrossRef] [PubMed]

32. Skrzypulec, V.; Olejek, A.; Drosdzol, A.; Nowosielski, K.; Kozak-Darmas, I.; Wloch, S. Sexual functions and depressive symptoms after photodynamic therapy for vulvar lichen sclerosus in postmenopausal women from the Upper Silesian Region of Poland. J. Sex. Med. 2009, 6, 3395-3400. [CrossRef] [PubMed]

33. Osiecka, B.J.; Nockowski, P.; Jurczyszyn, K.; Ziólkowski, P. Photodynamic therapy of vulvar lichen sclerosus et atrophicus in a woman with hypothyreosis-Case report. Photodiagnosis Photodyn. Ther. 2012, 9, 186-188. [CrossRef] [PubMed]

34. Imbernón-Moya, A.; Martínez-Pérez, M.; Churruca-Grijelmo, M.; Lobato-Berezo, A.; Vargas-Laguna, E.; Fernández-Cogolludo, E.; Aguilar-Martínez, A.; Gallego-Valdés, M.Á. Photodynamic therapy as a therapeutic alternative in vulvar lichen sclerosus: Series of 8 cases. Photodermatol. Photoimmunol. Photomed. 2016, 32, 307-310. [CrossRef]

35. Osiecka, B.J.; Jurczyszyn, K.; Nockowski, P.; Murawski, M.; Ziółkowski, P. Photodynamic therapy with green light for the treatment of vulvar lichen sclerosus-Preliminary results. Photodiagnosis Photodyn. Ther. 2017, 17, 185-187. [CrossRef] [PubMed]

36. Maździarz, A.; Osuch, B.; Kowalska, M.; Nalewczyńska, A.; Śpiewankiewicz, B. Photodynamic therapy in the treatment of vulvar lichen sclerosus. Photodiagnosis Photodyn. Ther. 2017, 19, 135-139. [CrossRef]

37. Olejek, A.; Gabriel, I.; Bilska-Janosik, A.; Kozak-Darmas, I.; Kawczyk-Krupka, A. ALA-Photodynamic treatment in Lichen sclerosus-clinical and immunological outcome focusing on the assesment of antinuclear antibodies. Photodiagnosis Photodyn. Ther. 2017, 18, 128-132. [CrossRef]

38. Lan, T.; Zou, Y.; Hamblin, M.R.; Yin, R. 5-Aminolevulinic acid photodynamic therapy in refractory vulvar lichen sclerosus et atrophicus: Series of ten cases. Photodiagnosis Photodyn. Ther. 2018, 21, 234-238. [CrossRef]

39. Maździarz, A. Successful pregnancy and delivery following selective use of photodynamic therapy in treatment of cervix and vulvar diseases. Photodiagnosis Photodyn. Ther. 2019, 28, 65-68. [CrossRef]

40. Zhang, F.; Li, D.; Shi, L.; Gu, Y.; Xu, Y. 5-ALA-photodynamic therapy in refractory vulvar lichen sclerosus et atrophicus. Int. J. Clin. Exp. Pathol. 2020, 13, 3100-3110.

41. Li, Z.; Wang, Y.; Wang, J.; Li, S.; Xiao, Z.; Feng, Y.; Gu, J.; Li, J.; Peng, X.; Li, C.; et al. Evaluation of the efficacy of 5-aminolevulinic acid photodynamic therapy for the treatment of vulvar lichen sclerosus. Photodiagnosis Photodyn. Ther. 2020, 29, 101596. [CrossRef]

42. Cao, Y.; Zhang, G.; Wang, P.; Li, C.; Wang, X. Treatment of Hyperkeratotic Vulvar Lichen Sclerosus with combination of holmium laser therapy and ALA-PDT: Case report. Photodiagnosis Photodyn. Ther. 2020, 31, 101762. [CrossRef] [PubMed]

43. Liu, J.; Hao, J.; Wang, Y.; Liu, Y.; Xu, T. Clinical and Dermoscopic Assessment of Vulvar Lichen Sclerosus after 5-Aminolevulinic Acid Photodynamic Therapy: A Prospective Study. Photodiagnosis Photodyn. Ther. 2021, 33, 102109. [CrossRef] [PubMed]

44. Zhang, F.; Li, D.; Shi, L.; Gu, Y.; Xu, Y.; Wu, C. Efficacy of 5-Aminolevulinic Acid (ALA)-Photodynamic Therapy (PDT) in Refractory Vulvar Lichen Sclerosus: Preliminary Results. Med. Sci. Monit. 2021, 27, e927406. [CrossRef]

45. Zielińska, A.; Maździarz, A.; Abdalla, N.; Sawicki, W.; Dmoch-Gajzlerska, E. Does HPV infection have impact on results of photodynamic treatment of vulvar lichen sclerosus? Photodiagnosis Photodyn. Ther. 2021, 34, 102138. [CrossRef] [PubMed]

46. Nguyen, K.; Khachemoune, A. An update on topical photodynamic therapy for clinical dermatologists. J. Dermatol. Treat. 2019, 30, 732-744. [CrossRef]

47. Kennedy, J.C.; Pottier, R.H.; Pross, D.C. Photodynamic therapy with endogenous protoporphyrin IX: Basic principles and present clinical experience. J. Photochem. Photobiol. B Biol. 1990, 6, 143-148. [CrossRef]

48. Corazza, M.; Schettini, N.; Zedde, P.; Borghi, A. Vulvar Lichen Sclerosus from Pathophysiology to Therapeutic Approaches: Evidence and Prospects. Biomedicines 2021, 9, 950. [CrossRef] [PubMed]

49. Goldstein, A.T.; Creasey, A.; Pfau, R.; Phillips, D.; Burrows, L.J. A double-blind, randomized controlled trial of clobetasol versus pimecrolimus in patients with vulvar lichen sclerosus. J. Am. Acad. Dermatol. 2011, 64, 99-104. [CrossRef]

50. Renaud-Vilmer, C.; Cavelier-Balloy, B.; Porcher, R.; Dubertret, L. Vulvar lichen sclerosus: Effect of long-term topical application of a potent steroid on the course of the disease. Arch. Dermatol. 2004, 140, 709-712. [CrossRef]

51. Shi, L.; Miao, F.; Zhang, L.L.; Zhang, G.L.; Wang, P.R.; Ji, J.; Wang, X.J.; Huang, Z.; Wang, H.W.; Wang, X.L. Comparison of 5-Aminolevulinic Acid Photodynamic Therapy and Clobetasol Propionate in Treatment of Vulvar Lichen Sclerosus. Acta Derm.-Venereol. 2016, 96, 684-688. [CrossRef] [PubMed]

52. Declercq, A.; Güvenç, C.; De Haes, P. Proposition of standardized protocol for photodynamic therapy for vulvar lichen sclerosus. J. Dermatolog. Treat. 2020, 1, 1-9. [CrossRef] [PubMed] 